\title{
Background aerosol over the Himalayas and Tibetan Plateau: observed characteristics of aerosol mass loading
}

\author{
Bin Liu ${ }^{1}$, Zhiyuan Cong ${ }^{1,4}$, Yuesi Wang ${ }^{2}$, Jinyuan $\mathrm{Xin}^{2}$, Xin Wan ${ }^{1}$, Yuepeng Pan ${ }^{2}$, Zirui Liu ${ }^{2}$, Yonghong Wang ${ }^{2}$, \\ Guoshuai Zhang ${ }^{1}$, Zhongyan Wang ${ }^{1}$, Yongjie Wang ${ }^{1}$, and Shichang Kang ${ }^{3,4}$ \\ ${ }^{1}$ Key Laboratory of Tibetan Environment Changes and Land Surface Processes, Institute of Tibetan Plateau Research, \\ Chinese Academy of Sciences (CAS), Beijing 100101, China \\ ${ }^{2}$ State Key Laboratory of Atmospheric Boundary Layer Physics and Atmospheric Chemistry (LAPC), \\ Institute of Atmospheric Physics, CAS, Beijing 100029, China \\ ${ }^{3}$ State Key Laboratory of Cryospheric Sciences, Cold and Arid Regions Environmental and Engineering Research Institute, \\ CAS, Lanzhou 730000, China \\ ${ }^{4}$ CAS Center for Excellence in Tibetan Plateau Earth Sciences, Chinese Academy of Sciences, Beijing 100101, China
}

Correspondence to: Shichang Kang (shichang.kang@1zb.ac.cn) and Zhiyuan Cong (zhiyuancong@itpcas.ac.cn)

Received: 26 July 2016 - Published in Atmos. Chem. Phys. Discuss.: 28 September 2016

Revised: 9 December 2016 - Accepted: 19 December 2016 - Published: 10 January 2017

\begin{abstract}
To investigate the atmospheric aerosols of the Himalayas and Tibetan Plateau (HTP), an observation network was established within the region's various ecosystems, including at the Ngari, Qomolangma (QOMS), Nam Co, and Southeastern Tibetan (SET) stations. In this paper we illustrate aerosol mass loadings by integrating in situ measurements with satellite and ground-based remote sensing datasets for the 2011-2013 period, on both local and large scales. Mass concentrations of these surface atmospheric aerosols were relatively low and varied with land cover, showing a general tendency of Ngari and QOMS (barren sites) > Nam Co (grassland site) > SET (forest site). Daily averages of online $\mathrm{PM}_{2.5}$ (particulates with aerodynamic diameters below $2.5 \mu \mathrm{m}$ ) at these sites were sequentially $18.2 \pm 8.9,14.5 \pm 7.4,11.9 \pm 4.9$ and $11.7 \pm 4.7 \mu \mathrm{g} \mathrm{m}^{-3}$. Correspondingly, the ratios of $\mathrm{PM}_{2.5}$ to total suspended particles (TSP) were $27.4 \pm 6.65,22.3 \pm 10.9,37.3 \pm 11.1$ and $54.4 \pm 6.72 \%$. Bimodal mass distributions of sizesegregated particles were found at all sites, with a relatively small peak in accumulation mode and a more notable peak in coarse mode. Diurnal variations in fine-aerosol masses generally displayed a bi-peak pattern at the QOMS, Nam Co and SET stations and a single-peak pattern at the Ngari station, controlled by the effects of local geomorphology, mountainvalley breeze circulation and aerosol emissions. Dust aerosol content in $\mathrm{PM}_{2.1}$ samples gave fractions of $26 \%$ at the Ngari
\end{abstract}

station and $29 \%$ at the QOMS station, or $\sim 2-3$ times that of reported results at human-influenced sites. Furthermore, observed evidence confirmed the existence of the aerodynamic conditions necessary for the uplift of fine particles from a barren land surface. Combining surface aerosol data and atmospheric-column aerosol optical properties, the TSP mass and aerosol optical depth (AOD) of the Multi-angle Imaging Spectroradiometer (MISR) generally decreased as land cover changed from barren to forest, in inverse relation to the $\mathrm{PM}_{2.5}$ ratios. The seasonality of aerosol mass parameters was land-cover dependent. Over forest and grassland areas, TSP mass, $\mathrm{PM}_{2.5}$ mass, MISR-AOD and fine-mode AOD were higher in spring and summer, followed by relatively lower values in autumn and winter. At the barren site (the QOMS station), there were inconsistent seasonal patterns between surface TSP mass $\left(\mathrm{PM}_{2.5}\right.$ mass) and atmospheric column AOD (fine-mode AOD). Our findings implicate that HTP aerosol masses (especially their regional characteristics and fine-particle emissions) need to be treated sensitively in relation to assessments of their climatic effect and potential role as cloud condensation nuclei and ice nuclei. 


\section{Introduction}

Atmospheric aerosols undergo changes in their microphysical, chemical and optical properties, especially in highaltitude mountainous regions. These changes primarily determine their roles in modifying regional climate, cryosphere and hydrology. This is particularly true for the Himalayan and Tibetan Plateau (HTP) region, which is surrounded by Asian dust and strong anthropogenic emissions. These natural and manmade airborne chemicals, such as light-absorbing materials, reactive nitrogen and heavy metals, can impact regional monsoon rainfall (e.g., Ramanathan et al., 2005; Lau et al., 2006), snow-ice albedo (e.g., Ming et al., 2008; Xu et al., 2009; Qu et al., 2014), nitrogen deposition (Liu et al., 2013, 2015) and meltwater composition (e.g., Zhang et al., 2015). Although these effects remain poorly understood, it is of first-order importance to characterize these remote atmospheric aerosols.

In the HTP, aerosol optical properties and chemical compositions have been observed almost entirely at a few specific sites. Ground-based measurements have focused on the relatively small concentrations of fine particles and total suspended particles (TSPs) in the HTP atmospheric surface layer (Zhao et al., 2013; Xu et al., 2014). Satellite and ground-based remote sensing have also been employed and have pointed to a low aerosol optical depth (AOD) in this region (Xia et al., 2008, 2011; Yan et al., 2015). Mineral dust has been identified as one of the main aerosol components in the central Himalayas (Decesari et al., 2010) and the central TP (Zhang et al., 2001; Cong et al., 2007; Kang et al., 2016). Analysis of dust plumes from the surrounding deserts (the Taklimakan, Gobi and southwest Asian deserts) has indicated some potential source areas of atmospheric particulates (Huang et al., 2007; Liu et al., 2008; Xia et al., 2008). However, these results have revealed only the somewhat pristine characteristics of HTP aerosols, dependent largely upon a significant understanding of mineral dust. Much uncertainty remains over the correct evaluation of aerosol sources, transportation and deposition, especially in relation to a much wider variety of aerosol species. Furthermore, the mountains produce extensive mountain-valley breezes, alpine glacier and snow, and stratosphere-troposphere exchanges. These conditions could in turn affect aerosol properties via transportation and chemical processes by facilitating the upward diffusion of aerosol matters (Decesari et al., 2010; Cong et al., 2015) and by changing the oxidizing capacity of the troposphere (Lin et al., 2008). Hence, there are additional obstacles in understanding HTP atmospheric aerosols.

Anthropogenic emissions into this region occur occasionally and are dependent on local and large-scale atmospheric dynamics. During the pre-monsoon period, "atmospheric brown cloud" stacks up in the southern foothills of the Himalayas (Ramanathan et al., 2001). Mountain-valley breeze circulations allow these aerosols to spread upslope and then enhance the concentrations of carbonaceous and inorganic matters in fine aerosols over the Himalayas (Decesari et al., 2010; Babu et al., 2011; Cong et al., 2015; Lüthi et al., 2015). The Westerlies transport of air pollutants is dominant in the western TP (Cao et al., 2009). Additionally, the South Asian monsoon system is one of the important atmospheric dynamics in the transport of pollutants to the southeastern TP from southern and southeastern Asia (Liu et al., 2013; Sheng et al., 2013). Consequently, light-absorbing substances (such as black carbon) have received special attention. Studies have raised different hypotheses concerning aerosol impacts, including a suppression of the Southern Asian monsoon through a weakening of the meridional surface temperature gradient (Ramanathan et al., 2005) and an increase of regional monsoonal rainfall in northern India, the Himalayas and the southern Tibetan Plateau (TP) through the "elevated-heat-pump" effect (Lau et al., 2006). Furthermore, the post-depositional effect of decreasing snow-ice albedo is likely to lead to reductions in the HTP glaciers (Xu et al., 2009; Ming et al., 2012; Qu et al., 2014). However, the validity of these hypotheses strongly depends on the characteristics and spatiotemporal variations in these particles (principally in mass loadings, chemical compositions, size distributions and optical properties) and their related atmospheric processes.

In general, the HTP, as a unique upland region where the relatively pristine tropospheric environment is juxtaposed with Asian anthropogenic emissions, is highly suitable for the study of background atmospheric aerosols and the interactions between natural and anthropogenic emissions, processes which may have far-reaching environmental and climatic consequences (Lawrence, 2011; Vernier et al., 2011).

It was imperative, therefore, that the first comprehensive observation of HTP atmospheric background aerosols was conducted during the 2011-2013 period, based on four stations located in different ecosystems. Accordingly, we present in this study online $\mathrm{PM}_{2.5}$ (particles with aerodynamic diameters $\leq 2.5 \mu \mathrm{m}$ ) concentrations and filter-sampled particles, as well as the size distributions of these sizesegregated particles (Sect. 3.1). The diurnal variations in fine-aerosol masses are also discussed with particular reference to local geomorphology, source emissions and meteorological settings (Sect. 3.2). As part of our research, we attempted to integrate these in situ observations with aerosol optical properties derived from both ground-based and satellite remote sensing, aiming to construct a topographical view of their spatial and seasonal patterns (Sect. 3.3).

\section{Materials and methods}

\subsection{Monitoring sites and the regional environment}

The HTP is the greatest upland region of the Eurasian continent in the Northern Hemisphere's middle-low latitudes and composes landscapes covered mainly by alpine 
Table 1. Geographical conditions and aerosol observations at HTP background sites (Ngari, QOMS, Nam Co and SET stations).

\begin{tabular}{|c|c|c|c|c|c|c|}
\hline Station & Location & $\begin{array}{l}\text { Altitude } \\
\text { (a.s.1.) }\end{array}$ & Description & Research content & Observation & Instrumentation \\
\hline $\begin{array}{l}\text { Ngari } \\
\text { station }\end{array}$ & $\begin{array}{l}79^{\circ} 42^{\prime} \mathrm{E} \\
33^{\circ} 23^{\prime} \mathrm{N}\end{array}$ & $4264 \mathrm{~m}$ & $\begin{array}{l}\text { Semi-arid area, } \\
\text { western TP }\end{array}$ & $\begin{array}{l}\text { 1. Online and size } \\
\text { distribution of } \\
\text { aerosol masses }\end{array}$ & $\begin{array}{l}\text { 1. } \mathrm{PM}_{2.5}(5 \mathrm{~min}) \text { and nine- } \\
\text { stage aerosol mass (weekly) }\end{array}$ & $\begin{array}{l}\text { TEOM RP1400 and nine- } \\
\text { stage Anderson samplers }\end{array}$ \\
\hline $\begin{array}{l}\text { QOMS } \\
\text { station }\end{array}$ & $\begin{array}{l}86^{\circ} 57^{\prime} \mathrm{E} \\
28^{\circ} 21^{\prime} \mathrm{N}\end{array}$ & $4300 \mathrm{~m}$ & $\begin{array}{l}\text { North slope of } \\
\text { the central } \\
\text { Himalayas }\end{array}$ & $\begin{array}{l}\text { 2. Chemical composition } \\
\text { and matter closure } \\
\text { of size-segregated } \\
\text { aerosols }\end{array}$ & $\begin{array}{l}\text { Soluble salts, } \\
\text { heavy metals, OC } \\
\text { and EC (biweekly) }\end{array}$ & $\begin{array}{l}\text { IC, ICP-MS and thermal } \\
\text { optical carbon analyzer }\end{array}$ \\
\hline $\begin{array}{l}\text { Nam Co } \\
\text { station }\end{array}$ & $\begin{array}{l}90^{\circ} 57^{\prime} \mathrm{E} \\
30^{\circ} 46^{\prime} \mathrm{N}\end{array}$ & $4746 \mathrm{~m}$ & $\begin{array}{l}\text { Alpine grassland, } \\
\text { central TP }\end{array}$ & $\begin{array}{l}\text { 3. Aerosol optical } \\
\text { properties }\end{array}$ & $\begin{array}{l}\text { 3. Aerosol optical depth and } \\
\text { Ångström exponent (hourly) }\end{array}$ & $\begin{array}{l}\text { Microtops II } \\
\text { sun photometer at the } \\
\text { Ngari } \\
\text { and SET stations, } \\
{ }^{*} \text { CIMEL sun photometer } \\
\text { at the QOMS and } \\
\text { Nam Co stations }\end{array}$ \\
\hline $\begin{array}{l}\text { SET } \\
\text { station }\end{array}$ & $\begin{array}{l}94^{\circ} 44^{\prime} \mathrm{E} \\
29^{\circ} 46^{\prime} \mathrm{N}\end{array}$ & $3326 \mathrm{~m}$ & $\begin{array}{l}\text { Alpine forest, } \\
\text { southeastern TP }\end{array}$ & & & \\
\hline
\end{tabular}

forest, grassland and/or meadow, barren areas, and patchy glacier and/or snow cover. We take "upland" in the HTP region to be land above $2800 \mathrm{~m}$ a.s.1.; thus, this region has an upland area of $\sim 5000000 \mathrm{~km}^{2}$ (Fig. 1a). Four comprehensive observation platforms were established within different landscapes, including the Ngari station $\left(79^{\circ} 42^{\prime} \mathrm{E}\right.$, $33^{\circ} 23^{\prime} \mathrm{N}, 4264 \mathrm{~m}$ a.s.1.), the Qomolangma-Everest (QOMS) station $\left(86^{\circ} 57^{\prime} \mathrm{E}, 28^{\circ} 21^{\prime} \mathrm{N}, 4300 \mathrm{~m}\right.$ a.s.l.), the Nam Co station $\left(90^{\circ} 57^{\prime} \mathrm{E}, 30^{\circ} 46^{\prime} \mathrm{N}, 4,746 \mathrm{~m}\right.$ a.s.1.) and the Southeastern Tibet (SET) station $\left(94^{\circ} 44^{\prime} \mathrm{E}, 29^{\circ} 46^{\prime} \mathrm{N}, 3,326 \mathrm{~m}\right.$ a.s.1.) (Figs. 1 and $\mathrm{S} 1$ in the Supplement). The high-altitude, inland topography produces a generally cold, arid and windy climate across most of the HTP. Additionally, the atmospheric circulation systems (including the South Asian monsoon, the East Asian monsoon, and the Westerlies) control the seasonal and spatial variations in precipitation patterns, i.e., winterspring precipitation in the western HTP (Pamir area), monsoonal rainfall in the southeastern and eastern TP and Himalayas, and sparse precipitation in the northern regions (Fig. S2 in the Supplement).

Records of daily air pressure $(P)$, temperature $(T)$, relative humidity (RH), precipitation amount (PA), horizontal wind speed (WS) and wind direction (WD) observed at these stations displayed regional variability and seasonality of meteorology in the HTP during 2011-2013 (Fig. 2). Generally, the levels of $P$ were clearly different and decreased with ascending altitude, showing values of $605.4 \pm 3.7 \mathrm{hPa}$ at the Ngari station, $604.6 \pm 3.2 \mathrm{hPa}$ at the QOMS station, $570.7 \pm 4.4 \mathrm{hPa}$ at the Nam Co station and $679.5 \pm 2.9 \mathrm{hPa}$ at the SET station ( \pm 1.0 standard error). The average horizontal WS values were $2.7 \pm 1.1,4.3 \pm 1.6,3.4 \pm 1.4$ and $1.1 \pm 0.7 \mathrm{~m} \mathrm{~s}^{-1}$ for the Ngari, QOMS, Nam Co and SET stations, respectively. The PA was controlled by Asian monsoon systems within annual ranges of 173.3-243.8, 444.2-488.2 and 436.6-905.8 $\mathrm{mm}$ at the QOMS, Nam Co and SET stations, respectively. The lowest annual PA (40.9-125.3 mm) and mean RH $(29.2 \pm 14.7 \%)$ were observed at the Ngari station. Compared to other stations, the greater seasonal variability in $T$ at the Ngari station, i.e., from the lowest value $\left(-10.6 \pm 4.8^{\circ} \mathrm{C}\right)$ in December-February to the highest value $\left(14.0 \pm 3.1^{\circ} \mathrm{C}\right)$ in June-August, can be explained by its position far inland and its attendant climate.

\subsection{Observation protocols for HTP atmospheric aerosols}

Detailed information of HTP aerosol measurements is presented in Table 1 and includes the physical, chemical and optical properties of atmospheric aerosols at the Ngari, QOMS, Nam Co and SET stations.

RP 1400 series tapered element oscillating microbalance (TEOM) machines were installed and operated at each station to collect $\mathrm{PM}_{2.5}$ data from autumn 2011 onwards. $\mathrm{PM}_{2.5}$ mass was weighed and quantified based on the oscillation frequency of the tapered tube (Patashnick and Rupprecht, 1991). Their values were recorded at 5 min intervals. Values ranged from 0 to $5 \mathrm{~g} \mathrm{~m}^{-3}$, with a resolution of $0.1 \mu \mathrm{g} \mathrm{m}^{-3}$ and a precision of $\pm 0.5 \mu \mathrm{g} \mathrm{m}^{-3}$ over a $24 \mathrm{~h}$ average (Xin et al., 2015). At each station, size-segregated airborne particles (with the diameters of $<0.43,0.43-0.65,0.65-1.1$, $1.1-2.1,2.1-3.3,3.3-4.7,4.7-5.8,5.8-9.0$ and $>9.0 \mu \mathrm{m})$ were collected weekly using airborne particle nine-stage samplers (Andersen Series 20-800, USA) at a flow rate of 28.3 $\mathrm{L} \mathrm{min}^{-1}$. Quartz filters and cellulose membranes (with diameters of $81 \mathrm{~mm}$ ) were applied alternately for measuring different chemical species, with a collection time of $72 \mathrm{~h}$ per 

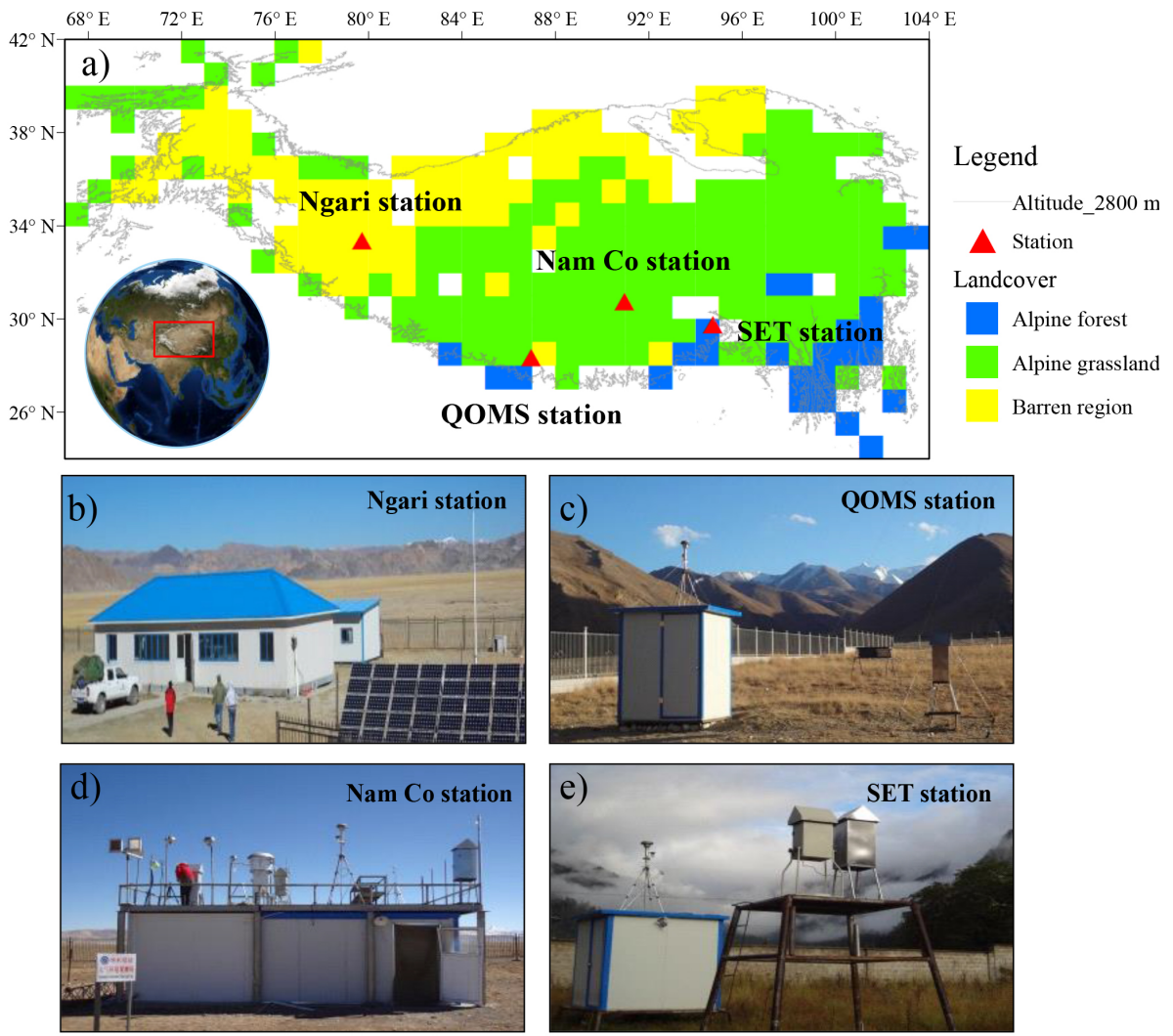

Figure 1. The main landscapes $\left(1^{\circ} \times 1^{\circ}\right.$ pixel resolution) (a) and the aerosol observation sites in the HTP (b-e). The highland HTP region is taken as land above $2800 \mathrm{~m}$ a.s.l., but the thresholds are $1500 \mathrm{~m}$ a.s.l. for areas $92-97^{\circ} \mathrm{E}$ and $26-34^{\circ} \mathrm{N}$, and $2000 \mathrm{~m}$ a.s. 1 . for areas $98-104^{\circ} \mathrm{E}$ and $24-34^{\circ} \mathrm{N}$, accounting for the regional deviations caused by the extremely steep topography. The classification of landscapes, according to MODIS land cover classification (Broxton et al., 2014), suggests different land covers at these stations (here the forest areas comprise evergreen, mixed, and deciduous forests).

Table 2. Concentrations $\left(\mu \mathrm{g} \mathrm{m}^{-3}\right)$ of hourly, daily and baseline $\mathrm{PM}_{2.5}$ and differences $\left(\mu \mathrm{g} \mathrm{m}^{-3}\right)$ between online and baseline $\mathrm{PM} 2.5$ at four HTP stations for 2011-2013. No. and SD stand for number and standard deviation, respectively.

\begin{tabular}{|c|c|c|c|c|c|c|c|c|c|c|c|c|}
\hline $\mathrm{PM}_{2.5}$ & No. & $\begin{array}{c}\text { Range } \\
\text { Ngari stati }\end{array}$ & Mean \pm SD & No. & $\begin{array}{l}\text { Range } \\
\text { QOMS sta }\end{array}$ & $\begin{array}{l}\text { Mean } \pm \text { SD } \\
\text { on }\end{array}$ & No. & $\begin{array}{c}\text { Range } \\
\text { Nam Co stat }\end{array}$ & Mean SD & \multicolumn{3}{|c|}{$\begin{array}{l}\text { Range Mean } \pm \text { S.D. } \\
\text { SET station }\end{array}$} \\
\hline Hourly & 1963 & 0.2 & 18.5 & 4049 & 0.1 & $13.8 \pm 12.3$ & 11067 & 0.2 & 118 & 6871 & 0.1 & 11.7 \\
\hline Daily & 88 & $7.1-77.3$ & $18.2 \pm 8.9$ & 236 & $2.6-48.1$ & $14.5 \pm 7.4$ & 480 & $3.9-43$ & 11 & 351 & $2.8-28.7$ & $11.7 \pm 4.7$ \\
\hline Baseli & 594 & 4.9 & + & 165 & $2.6-1$ & 9. & 88 & $3.3-$ & 9. & 4032 & $2.7-2$ & $9.2 \pm 3.0$ \\
\hline Online minus baseline & 1477 & $-16.3-109.7$ & $4.2 \pm 14.0$ & 1431 & $-15.7-53.7$ & $2.1 \pm 2.0$ & 8590 & $-17.7-33.0$ & $0.8 \pm 5.3$ & 3554 & $-13.9-49.4$ & $1.2 \pm 6.6$ \\
\hline
\end{tabular}

week (always from Monday to Wednesday). Before and after sampling, the filters were weighed using a microbalance (sensitivity $\pm 0.01 \mathrm{mg}$ ) after drying for $48 \mathrm{~h}$ at $25^{\circ} \mathrm{C}$ and $50 \%$ humidity (Xin et al., 2015). Mass concentrations of these filtered samples were in turn obtained according to the standard sampling volume.

\subsection{Methods of data analysis}

The baseline properties of atmospheric aerosol mass revealed a relatively stable and low aerosol loading, excluding possible perturbations (Kaufman et al., 2001; Xia et al., 2011). Following Kaufman et al. (2001), we calculated the median of 50 consecutive hourly average values of online $\mathrm{PM}_{2.5}$ masses over 2-3 days and removed data sequences with standard deviations higher than those of the whole time series by repeatedly shifting the running medians by one measurement point. The standard deviation thresholds were $24 \mu \mathrm{g} \mathrm{m}^{-3}$ at the Ngari station, $13 \mu \mathrm{g} \mathrm{m}^{-3}$ at the QOMS station, $9 \mu \mathrm{g} \mathrm{m}^{-3}$ at the Nam Co station and $11.7 \mu \mathrm{g} \mathrm{m}^{-3}$ at the SET station. Consequently, the remaining datasets were considered the time series of baseline $\mathrm{PM}_{2.5}$ masses.

We applied monthly Level 3 datasets of Multi-angle Imaging Spectroradiometer (MISR) to characterize atmospheric column AOD (at $550 \mathrm{~nm}$ ) over the HTP for 2011-2013. Level 


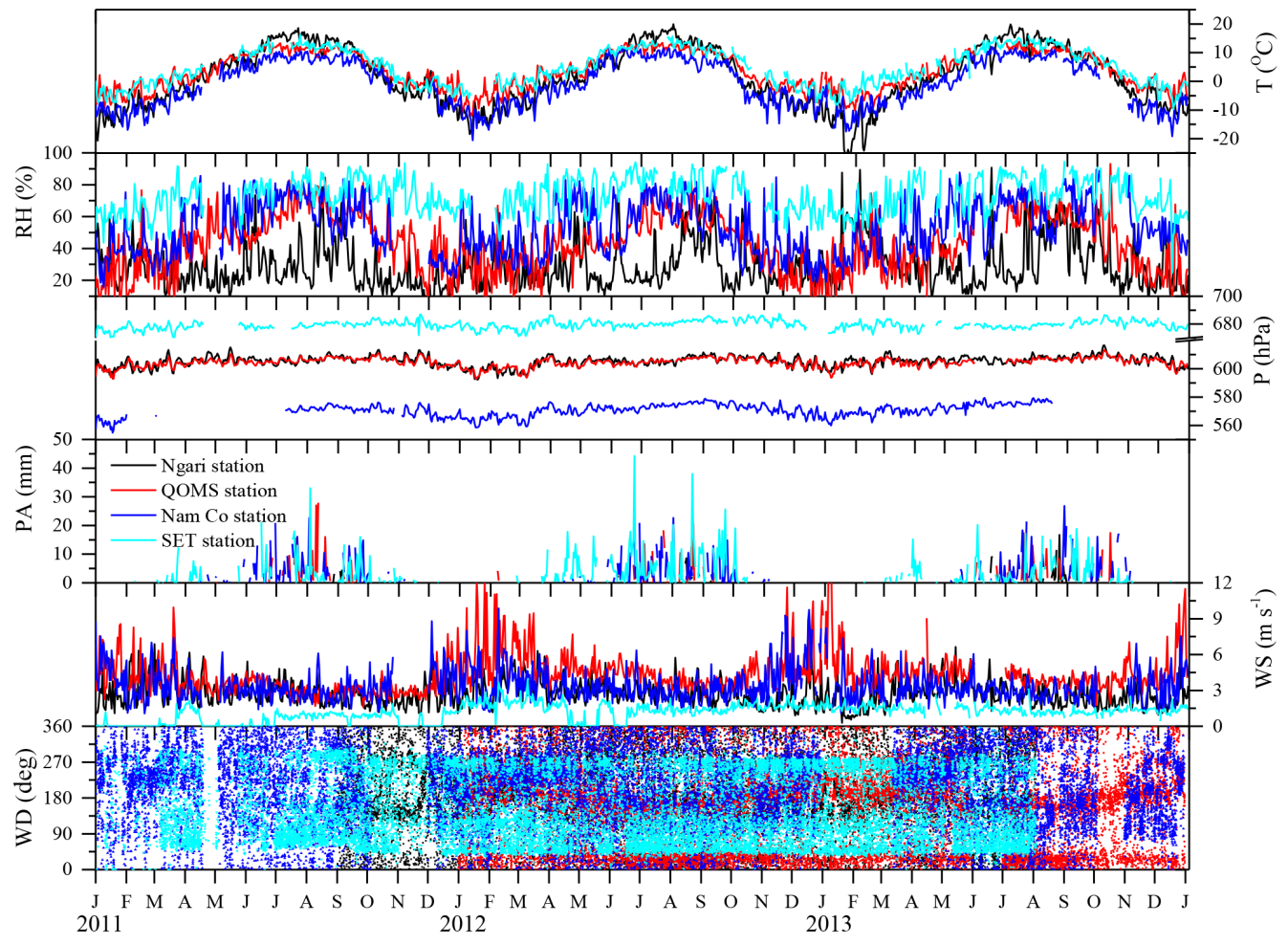

Figure 2. Time series for hourly air temperature $(T)$, relative humidity $(\mathrm{RH})$, pressure $(P)$, precipitation amount (PA), wind speed (WS) and wind direction (WD) in the HTP during 2011-2013 at the Ngari station (black), the QOMS station (red), the Nam Co station (blue) and the SET station (cyan), respectively.

2.0 Aerosol Robotic Network (AERONET) datasets at the QOMS station and Level 1.5 datasets at the Nam Co station were also used to address fine-mode AOD (at $500 \mathrm{~nm}$ ). A time-average map of the aerosol fine-mode fraction (at $550 \mathrm{~nm}$ ) for 2011-2013 was also constructed using monthly Moderate Resolution Imaging Spectrometer (MODIS) Terra (version 5.1) Level 3 values. Additionally, a global $0.5 \mathrm{~km}$ land cover climatology that derived from MODIS (Broxton et al., 2014) was converted to a $1^{\circ} \times 1^{\circ}$ pixel resolution using ArcGIS software, which provided the HTP's land cover datasets.

\section{Results and discussion}

\subsection{Mass concentrations of online $\mathbf{P M}_{2.5}$ and segregated particles}

Figure 3 and Table 2 show the time series and statistics for online $\mathrm{PM}_{2.5}$ measurements monitored at four HTP stations during 2011-2013. The daily mean concentrations were $18.2 \pm 8.9 \mu \mathrm{g} \mathrm{m}^{-3}$ at the Ngari station, $14.5 \pm 7.4 \mu \mathrm{g} \mathrm{m}^{-3}$ at the QOMS station, $11.9 \pm 4.9 \mu \mathrm{g} \mathrm{m}^{-3}$ at the Nam Co station and $11.7 \pm 4.7 \mu \mathrm{g} \mathrm{m}^{-3}$ at the SET station. Fine-aerosol masses were therefore generally low but variable against various background atmospheres. These results were compara- ble with the monitored values of $11.7 \pm 15.5 \mu \mathrm{g} \mathrm{m}^{-3}$ at a station in the Qilian Shan in the northeastern TP (Xu et al., 2014) and $26.6 \pm 19.3 \mu \mathrm{g} \mathrm{m}^{-3}$ at a background Himalayan site (Panwar et al., 2013).

Baseline levels of hourly $\mathrm{PM}_{2.5}$ mass were estimated to be $11.2 \pm 3.2 \mu \mathrm{g} \mathrm{m}^{-3}$ at the Ngari station, $9.8 \pm 3.1 \mu \mathrm{g} \mathrm{m}^{-3}$ at the QOMS station, $9.8 \pm 3.6 \mu \mathrm{g} \mathrm{m}^{-3}$ at the Nam Co station and $9.2 \pm 3.0 \mu \mathrm{g} \mathrm{m}^{-3}$ at the SET station (Table 2). The discrepancies between online $\mathrm{PM}_{2.5}$ and their baselines were also calculated. Consequently, average percentages and concentration levels were $\sim 22.7 \%$ and $4.2 \pm 14.0 \mu \mathrm{g} \mathrm{m}^{-3}$ at the Ngari station, $\sim 16.6 \%$ and $2.1 \pm 2.0 \mu \mathrm{g} \mathrm{m}^{-3}$ at the QOMS station, $\sim 6.8 \%$ and $0.8 \pm 5.3 \mu \mathrm{g} \mathrm{m}^{-3}$ at the Nam Co station, and $\sim 10.3 \%$ and $1.2 \pm 6.6 \mu \mathrm{g} \mathrm{m}^{-3}$ at the SET station (Table 2). Therefore, relatively great distinctions were found at the Ngari and QOMS stations. Significant variations, indicated by their daily frequency curves, also occurred at the Ngari and QOMS stations and were associated with episodes of high-concentration events (Fig. 4). These results implied a disturbance in the high-concentration aerosol masses of inland Asia associated with possible dust impact and dependent upon proximity to local arid and barren areas (for their typical landscapes, see Fig. S1 in the Supplement).

We further assessed mineral matter content in fine particles by analyzing elements in $\mathrm{PM}_{2.1}$ samples with inductively 


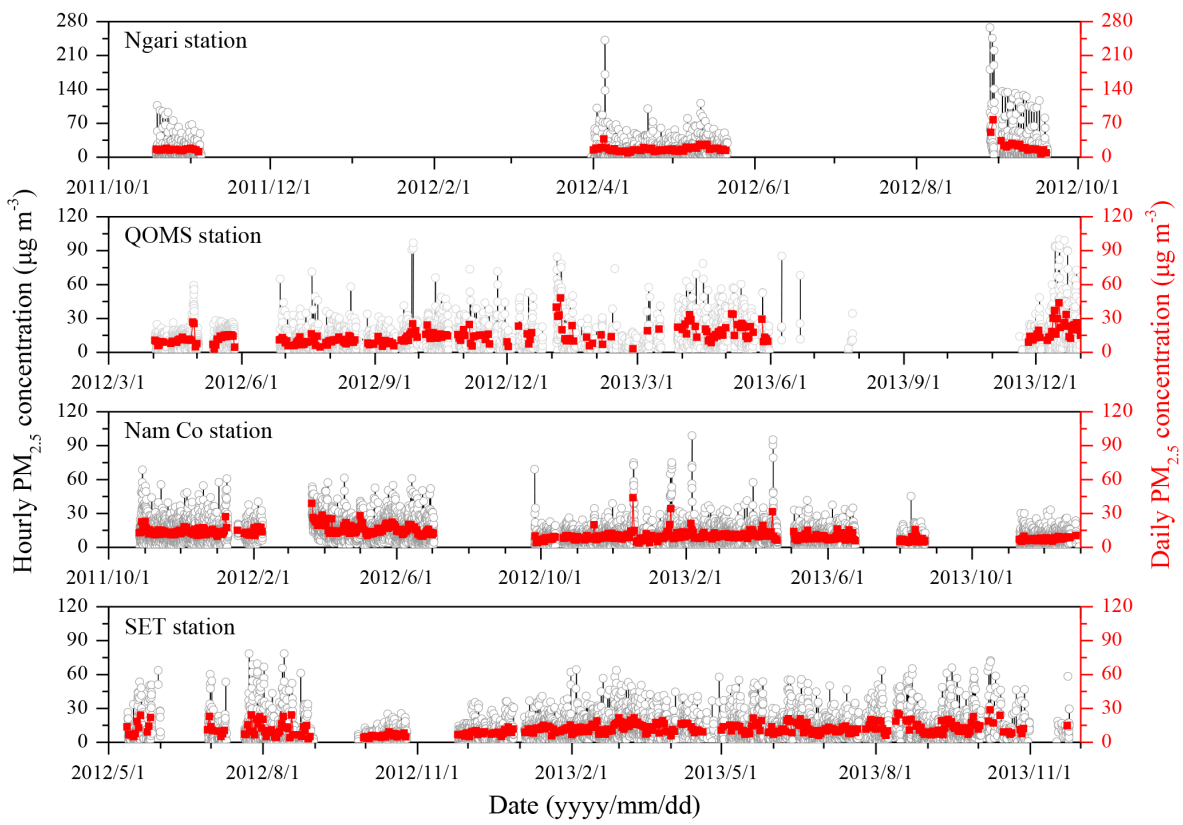

Figure 3. Hourly and daily mean concentrations $\left(\mu \mathrm{g} \mathrm{m}^{-3}\right)$ of $\mathrm{PM}_{2.5}$ at the Ngari station (October 2011-October 2012), the QOMS station (March 2012-December 2013), the Nam Co station (October 2011-December 2013) and the SET station (May 2011-December 2013) in the HTP. Periods with no data were due to power supply problems or equipment breakdown. A daily mean was calculated only when at least eight hourly means were available during that day.

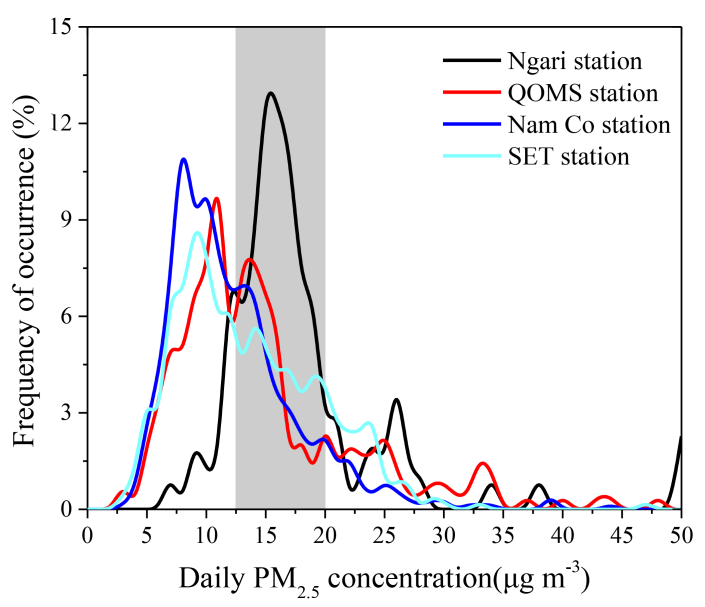

Figure 4. Frequency distributions of daily $\mathrm{PM}_{2.5}$ concentrations over the HTP observed during the 2011-2013 period. Highconcentration peaks around the range of $12.5-20 \mu \mathrm{g} \mathrm{m}^{-3}$ occurred in the frequency curves of the Ngari and QOMS stations, as indicated by the grey shading. The maximum $\mathrm{PM}_{2.5}$ bin concentration was set to $50 \mu \mathrm{g} \mathrm{m}^{-3}$, although a small fraction existed at higher concentrations.

coupled plasma mass spectroscopy (ICP-MS). Mineral matter content was assumed to be a mixture of mainly crustal oxides, i.e., $\mathrm{SiO}_{2}, \mathrm{Al}_{2} \mathrm{O}_{3}, \mathrm{CaO}, \mathrm{Fe}_{2} \mathrm{O}_{3}, \mathrm{~K}_{2} \mathrm{O}, \mathrm{Na}_{2} \mathrm{O}$ and $\mathrm{MgO}$. A detailed description of this approach can be found in Xin et al. (2015) (also see Table S1 in the Supplement). Mineral content was $26 \%$ at the Ngari station and $29 \%$ at the QOMS station. Our measurements revealed the impact of regional dust emissions, even for fine particles, over the HTP's barren areas. Proportions were 2-3 times those of $\mathrm{PM}_{2.1}$ (mean content $10.8 \%$ ) measured at a suburban site impacted by heavy air pollutants in North China (Xin et al., 2015) and $\mathrm{PM}_{2.0}$ (content of $14 \pm 4 \%$ ) sampled at a human-influenced site in Hungary (Maenhaut et al., 2005).

Table 3 shows the statistical results of segregated-particle mass loadings according to weekly filters. These particles exhibited a general tendency of the Ngari and QOMS stations (barren sites) $>$ Nam Co station (grassland site) $>$ SET station (forest site) in their mass levels, suggesting a potential effect associated with the HTP land cover. Furthermore, bimodal size distributions of surface-atmospheric particle masses occurred in these upland regions with an average pattern of a relatively small peak in accumulation mode and a more notable peak in coarse mode (Fig. 5). This represents an aerosol mass distribution pattern typical of continental background air (Willeke and Whitby, 1975). In previous studies, accumulation mode particles were observed at Mt. Waliguan observatory (Kivekäs et al., 2009), possibly formed by the coagulation or condensation of smaller aerosol particles. The effects of dust emission on coarser particles have been reported in the TP atmosphere (Zhang et al., 2001). 

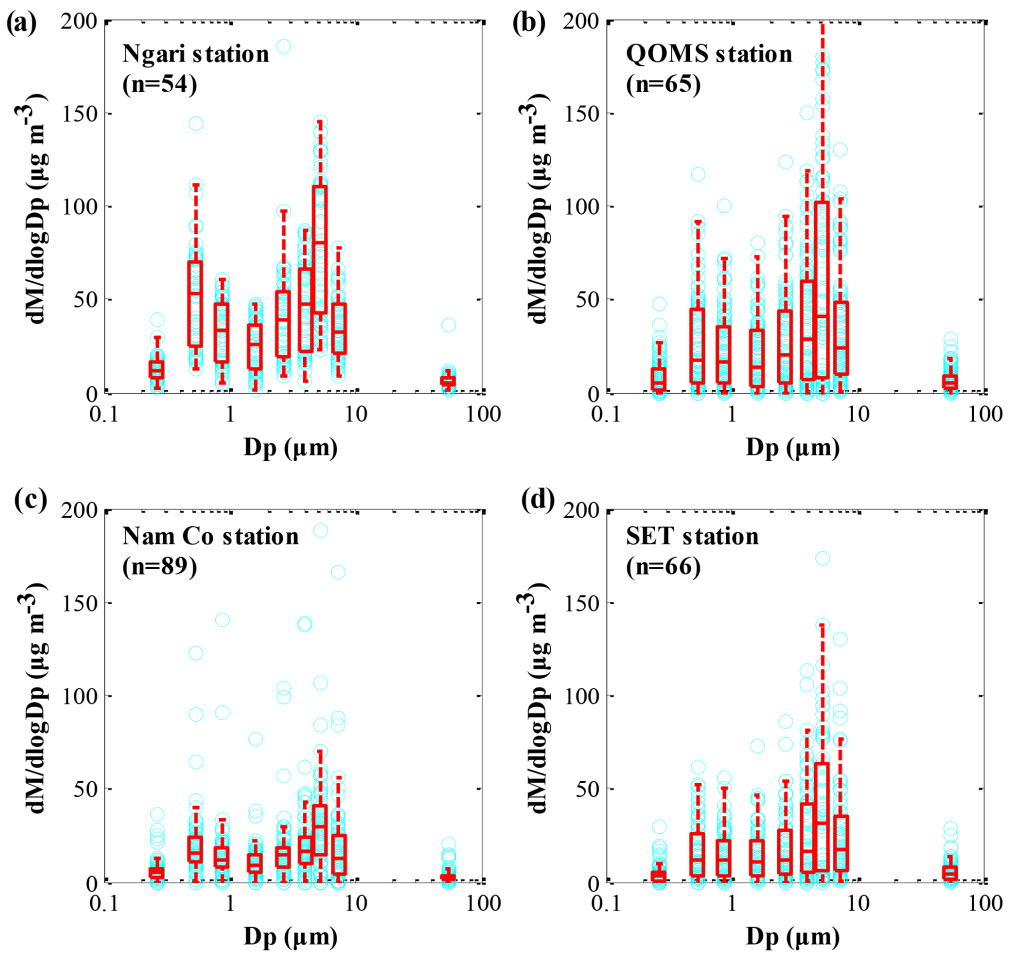

Figure 5. Size distributions of mass aerosol particles in the background surface atmosphere of the HTP (a: Ngari station, b: QOMS station, c: Nam Co station, d: SET station) as observed over the 2011-2013 period. Boxes show the percentile values $(25,50,75)$ and whisker plots show maximum and minimum of non-outlier numbers. The small blue circles behind the boxes are the distribution points.
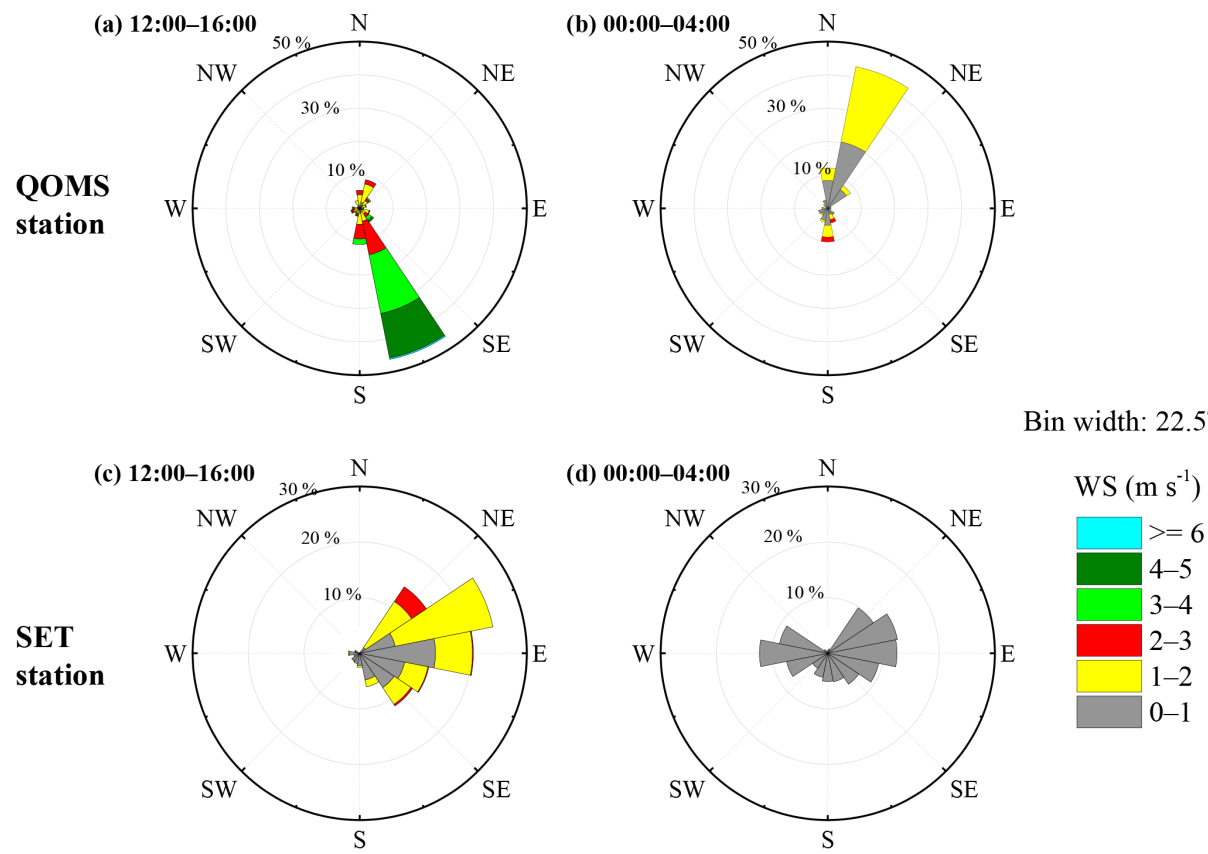

Figure 6. Wind rose plots for afternoon (12:00-16:00 LT) and nighttime (00:00-04:00 LT) in July and August at the QOMS station (a, b) and the SET station (c, d). An hourly horizontal wind direction (WD) was used, with its radii values expressed as percentages for wind blowing from particular directions. 


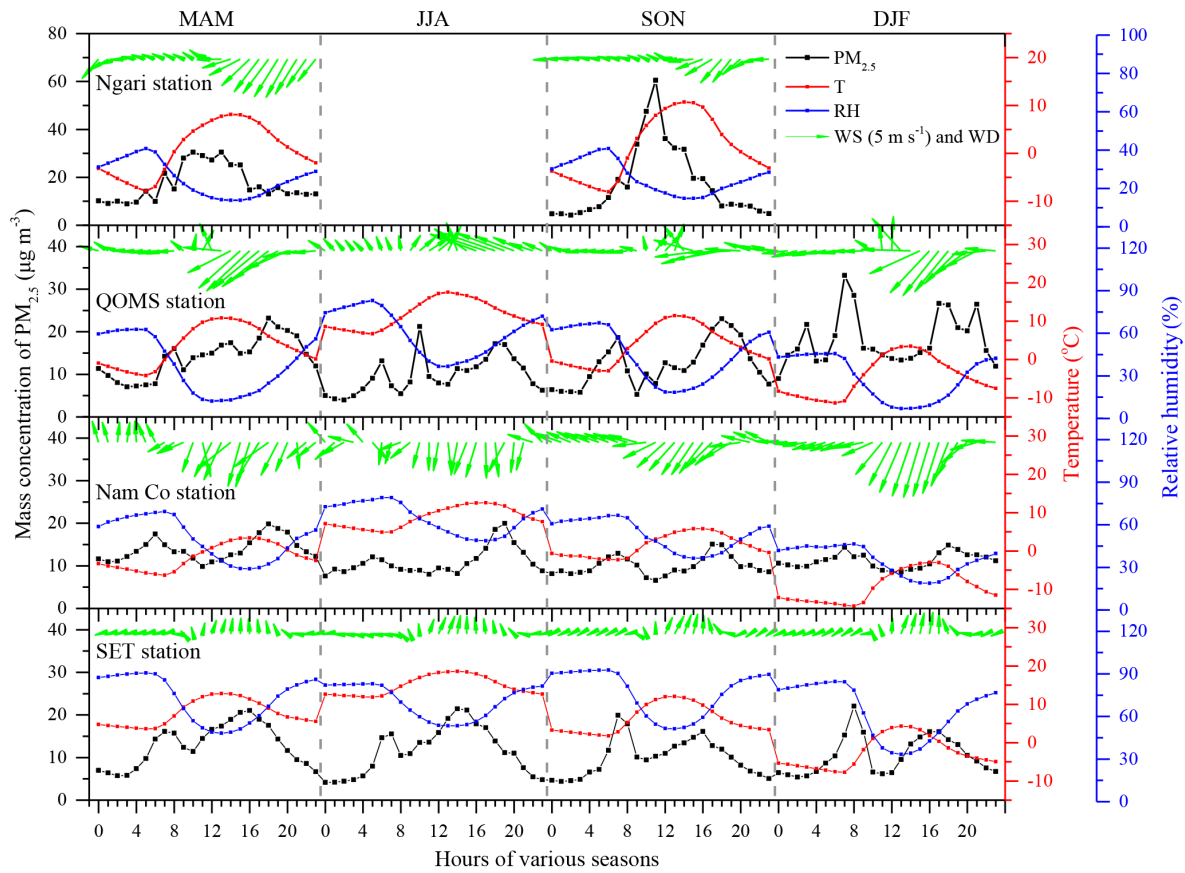

Figure 7. Seasonal diurnal variations in $\mathrm{PM}_{2.5}$ concentrations, air $T$ and $\mathrm{RH}$ over the 2011-2013 period at four background HTP sites (the Ngari station, the QOMS station, the Nam Co station and the SET station). The local time (LT) was used at each site according to longitudinal position.

(a)

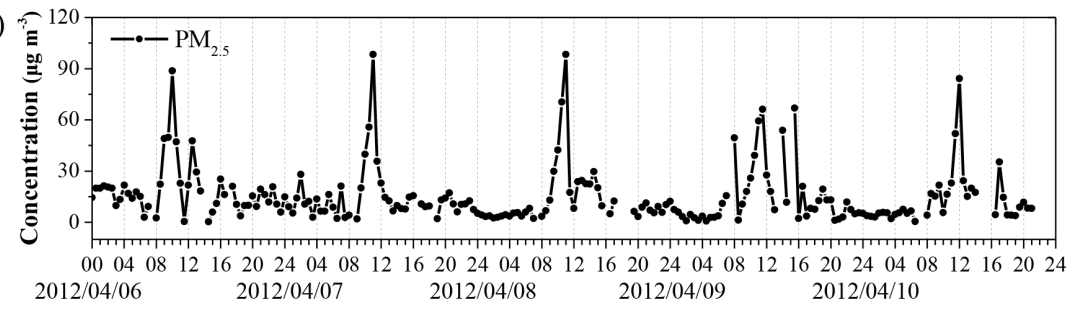

(b)

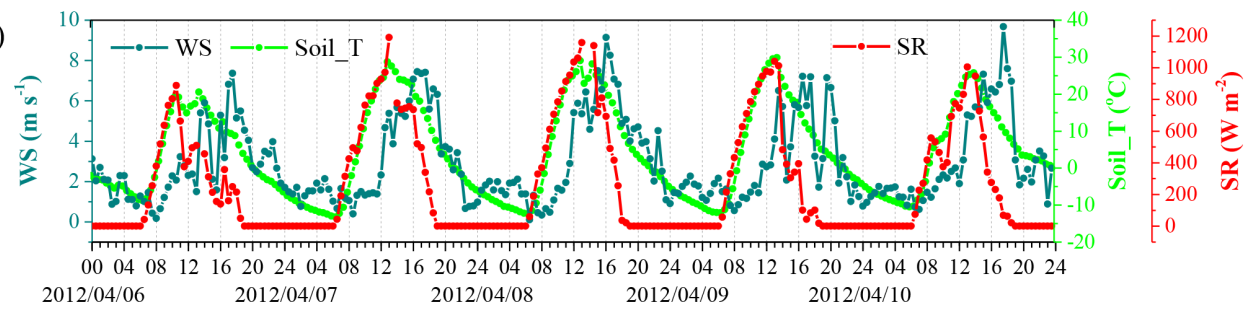

(c)

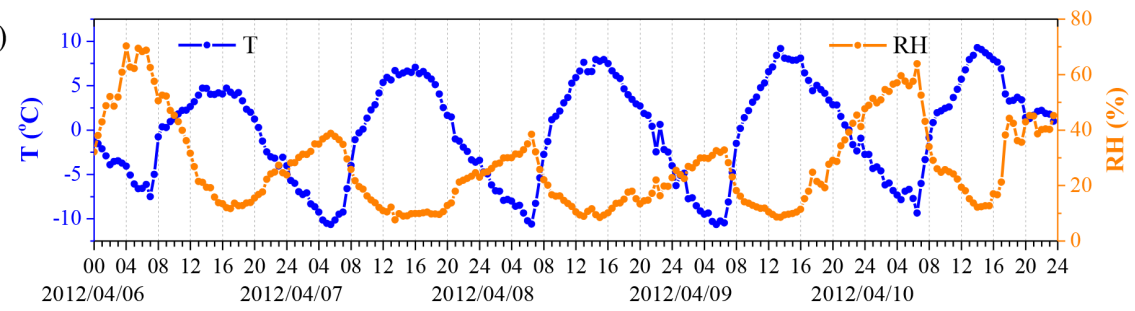

Figure 8. Diurnal variations in $\mathrm{PM}_{2.5}$ masses and related environmental factors for 6-10 April 2012 at the Ngari station (located in a typical barren and arid area of inland Asia). SR is downward shortwave radiation and soil $T$ is the surface soil temperature at $0 \mathrm{~cm}$. The local time (LT) and a 30 min mean were used. 
Table 3. Average mass concentrations \pm standard deviations $\left(\mu \mathrm{g} \mathrm{m}^{-3}\right.$ ) for size-segregated particles (at various $\mu \mathrm{m}$ ) and $\mathrm{PM}_{1.1}$, $\mathrm{PM}_{2.1}, \mathrm{PM}_{9}$ and TSP sampled from the HTP surface atmosphere during 2011-2013. No. stands for number of samples.

\begin{tabular}{lrrrr}
\hline Species & $\begin{array}{r}\text { Ngari } \\
\text { station }\end{array}$ & $\begin{array}{r}\text { QOMS } \\
\text { station }\end{array}$ & $\begin{array}{r}\text { Nam Co } \\
\text { station }\end{array}$ & $\begin{array}{r}\text { SET } \\
\text { station }\end{array}$ \\
\hline No. & 54 & 89 & 65 & 66 \\
$<0.43$ & $7.7 \pm 5.1$ & $5.8 \pm 6.0$ & $4.1 \pm 4.3$ & $2.6 \pm 2.6$ \\
$0.43-0.65$ & $8.8 \pm 5.8$ & $6.6 \pm 6.2$ & $3.7 \pm 3.4$ & $2.4 \pm 2.1$ \\
$0.65-1.1$ & $7.5 \pm 3.6$ & $6.5 \pm 5.0$ & $3.6 \pm 4.5$ & $2.6 \pm 2.2$ \\
$1.1-2.1$ & $7.0 \pm 3.8$ & $7.6 \pm 6.8$ & $3.2 \pm 3.1$ & $2.3 \pm 2.0$ \\
$2.1-3.3$ & $8.1 \pm 5.5$ & $7.1 \pm 5.5$ & $3.3 \pm 3.5$ & $2.3 \pm 2.1$ \\
$3.3-4.7$ & $7.2 \pm 3.6$ & $8.3 \pm 11.1$ & $3.4 \pm 3.8$ & $2.5 \pm 2.0$ \\
$4.7-5.8$ & $7.2 \pm 3.4$ & $8.3 \pm 10.5$ & $3.4 \pm 4.0$ & $2.4 \pm 2.2$ \\
$5.8-9$ & $7.8 \pm 7.1$ & $7.7 \pm 5.9$ & $3.7 \pm 4.9$ & $2.0 \pm 1.6$ \\
$>9$ & $5.6 \pm 8.2$ & $7.8 \pm 6.6$ & $3.5 \pm 4.1$ & $2.3 \pm 3.5$ \\
PM $_{1.1}$ & $24 \pm 14.5$ & $18.9 \pm 17.3$ & $11.3 \pm 12.2$ & $7.7 \pm 6.8$ \\
PM $_{2.1}$ & $30.6 \pm 14.2$ & $26.3 \pm 20.6$ & $14.5 \pm 12.9$ & $10.0 \pm 8.2$ \\
PM $_{9}$ & $60.9 \pm 27.5$ & $57.5 \pm 45.4$ & $28.4 \pm 25.9$ & $19.2 \pm 15.0$ \\
TSP & $66.4 \pm 29.6$ & $65.1 \pm 50.9$ & $31.9 \pm 29.0$ & $21.5 \pm 18.0$ \\
\hline
\end{tabular}

\subsection{Diurnal variations in mass concentrations of fine aerosols}

In these background atmospheres, the intensity of diurnal variabilities in $\mathrm{PM}_{2.5}$ masses was roughly characterized by their daytime (06:00-18:00 local time, $\mathrm{LT})$ to nighttime (18:00-06:00 LT) ratios. Their average ratios were $\sim 2.5$ at the Ngari station, $\sim 1.1$ at the QOMS station, $\sim 0.9$ at the Nam Co station and $\sim 1.8$ at the SET station, based on hourly observations during the 2011-2013 period.

Higher ratios were found in valleys around the QOMS and SET stations, suggesting a negative impact of mountainous valleys on the diffusion of local aerosol masses. The local geomorphology around these sites is displayed in Fig. S3 in the Supplement. Conversely, these topographical settings also produced mountain-valley wind circulations aligned with valley orientation, as identified in July and August (Fig. 6). We analyzed the hourly datasets for the summer monsoon period (July and August) since the mid-latitude westerlies are more prevalent during the other periods and thus constrain the influence of synoptic-scale wind. Horizontal WD at the QOMS station was consequently stronger and clearly inverse compared to that at the SET station. Such a topographically forced circulation can facilitate the spread of aerosols upslope (Decesari et al., 2010; Babu et al., 2011; Cong et al., 2015). This would explain the ratio being lower at the QOMS station than at the SET station. The Ngari station is located in a relatively open geomorphological setting, but experiences marked diurnal variations. This phenomenon can be attributed to the dust lift from the barren land surface in the daytime, as will be discussed below.

The overall patterns of diurnal variability in fine-aerosol mass, atmospheric $T$ and RH, as well as in horizontal WD, are shown in Fig. 7. These fine-particle masses begin to arise
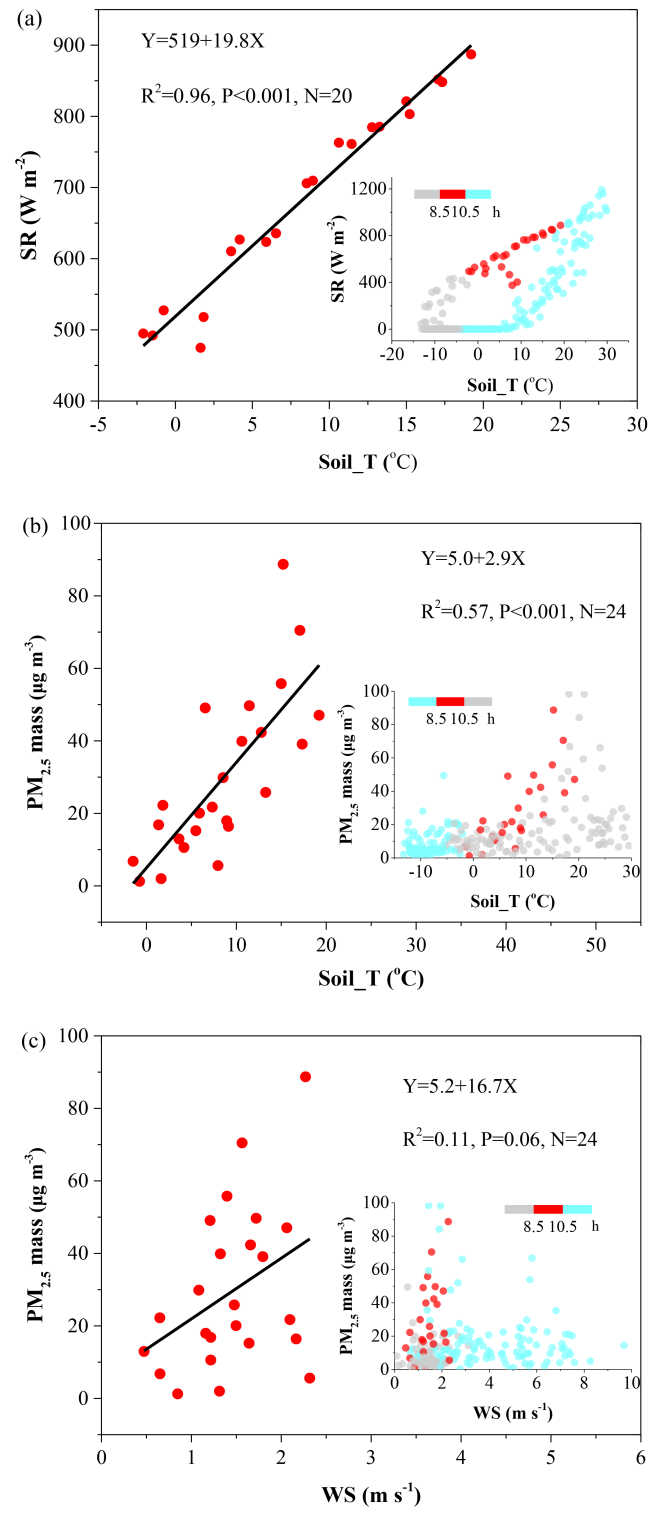

Figure 9. Correlations between $\mathrm{SR}$ and soil $T$ (a), soil $T$ and $\mathrm{PM}_{2.5}$ mass (b), and WS and $\mathrm{PM}_{2.5}$ mass (c) in the morning (08:30 10:30 LT) at the Ngari station for 6-10 April 2012. The smaller inserts show all recorded points within the measured time frame. Note that the fit line of Fig. 9a is for 6-9 April 2012 because there was a rainfall event ( 08:00-11:00 LT) on 10 April 2012, as indicated in Fig. 8. However, even if the dataset for 10 April 2012 is included, the fit line remains more or less consistent, with $R^{2}=0.61$ and $P<0.001$. The local time (LT) and a 30 min mean were used.

during 06:00-08:00 LT, accompanied by an increase in $T$ and a decrease in RH. Around noon (10:00-14:00 LT), concentrations decreased again, shown by the trough in their diurnal curves, coinciding with the highest $T$ and horizontal WD values, and the lowest RH. Consequently, bi-peak patterns in diurnal variations were especially marked for the Nam Co station (whole year), and for the QOMS and SET stations 
(a)

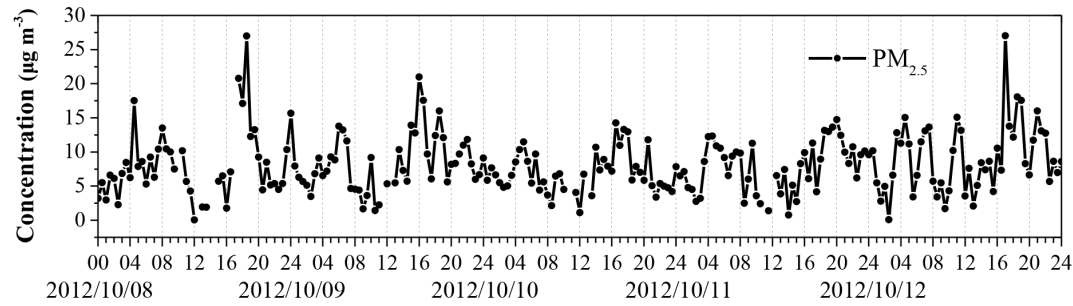

(b)

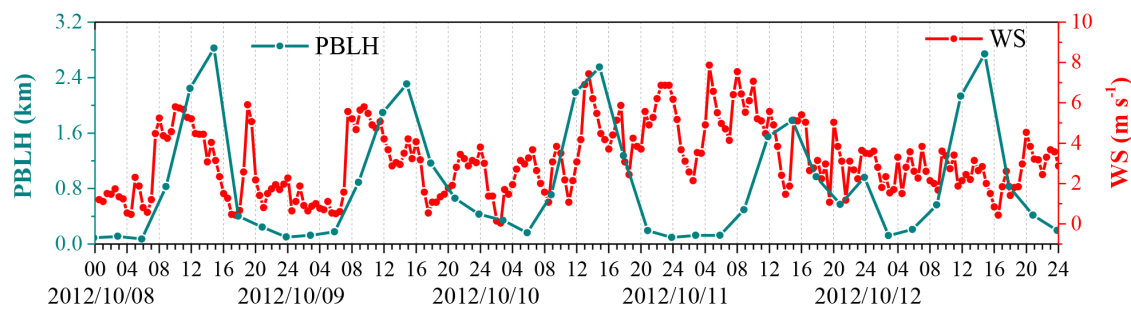

(c)

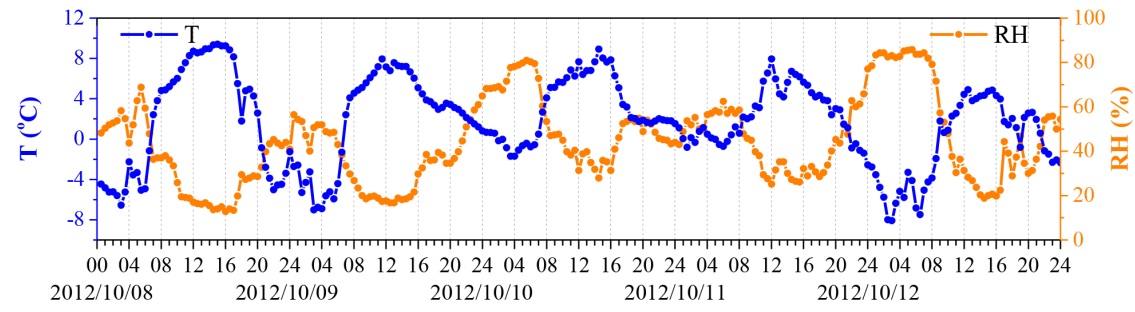

Figure 10. Diurnal variations in $\mathrm{PM}_{2.5}$ concentrations and related environmental factors for 8-12 October 2012 at the Nam Co station. Based on local time (LT), 30 min mean datasets were used.

(autumn and winter). In contrast, the Ngari station, in the arid Asian interior, evinced a single-peak pattern in diurnal variations. Such variations are typically found in dust provenances (Mbourou et al., 1997; Stout, 2010), resulting from the atmospheric and land surface conditions prevalent during the daytime.

In the cases of 6-10 April 2012, solar radiation (SR) imposed dramatic changes on the soil and atmospheric $T, \mathrm{RH}$ and WS in the morning (Figs. 8 and 9). Here, SR was taken as the downward shortwave radiation and the soil $T$ was the surface soil temperature at $0 \mathrm{~cm}$, measured using an automated weather system at the Ngari station. Increases in atmospheric $T$ and soil $T$, and a decline in $\mathrm{RH}$, were synchronous from 06:00 to 07:00 LT in response to solar heating. SR and soil $T$ values rose increasingly in tandem during the 08:3010:30 LT period, forming a very close relation $\left(R^{2}=0.96\right.$, $P<0.001$ ), apparently in response to the arid and barren setting and cloud-free air at that time (Figs. 8 and 9a). Hence, soil $T$ rose from $\sim-2.5$ to $\sim 20^{\circ} \mathrm{C}$ beyond the dew point temperature, and gradually dried out the surface moisture and uppermost layer of land (Fig. 9b). This in turn implied a reduction in the critical dust burst threshold for barren conditions (Stout, 2010). Furthermore, the rise in morning WS created an atmospheric dynamic suited to dust suspension in the late morning when fine materials were transported up from the land surface into the atmosphere (Fig. 8c). The combination of a declining critical dust burst threshold and favorable atmospheric fluctuation induced the increase in fine particles in the atmosphere with a peak near noontime. During the 14:00-18:00 LT period WS was strongest with a range of 4$10 \mathrm{~m} \mathrm{~s}^{-1}$. Dependent upon its intensity, WS can dilute fineparticle masses, rather than affect fine-particle fluctuations between sandy surfaces and the air. In addition, a decrease in saltation activity prior to the WS drop has frequently been observed in barren and arid continental interiors, possibly resulting from a reduction in turbulent wind fluctuations in the late afternoon (Stout, 2010). This effect can also restrict dust burst and thus its contribution to ambient fine-particle content. These in situ observations established that land surface and low-layer atmosphere are the key physical controls of the diurnal $\mathrm{PM}_{2.5}$ mass cycle at the Ngari station. They also confirmed that local dust emissions contributed to the chemical composition of fine aerosols.

Bi-peak-like diurnal variations in the $\mathrm{PM}_{2.5}$ masses at the Nam Co station, located in a grassland site near the great Nam Co Lake (Fig. S3 in the Supplement), are shown in Fig. 10. The planetary boundary layer height (PBLH) was derived from National Center for Environmental Prediction reanalysis data, which used a $1^{\circ} \times 1^{\circ}$ pixel and a $3 \mathrm{~h}$ temporal resolution (http://www.arl.noaa.gov/gdas1.php). In response to increasing $T$, the PBLH rose during the daytime from $<100$ to $>2500 \mathrm{~m}$, associated with a rise in WS (Fig. 10). This combination of factors resulted in a marked diffusion of fine particles, shown by the trough in $\mathrm{PM}_{2.5}$ concentrations 
(a) TSP concentration and MISR AOD (at $550 \mathrm{~nm})$

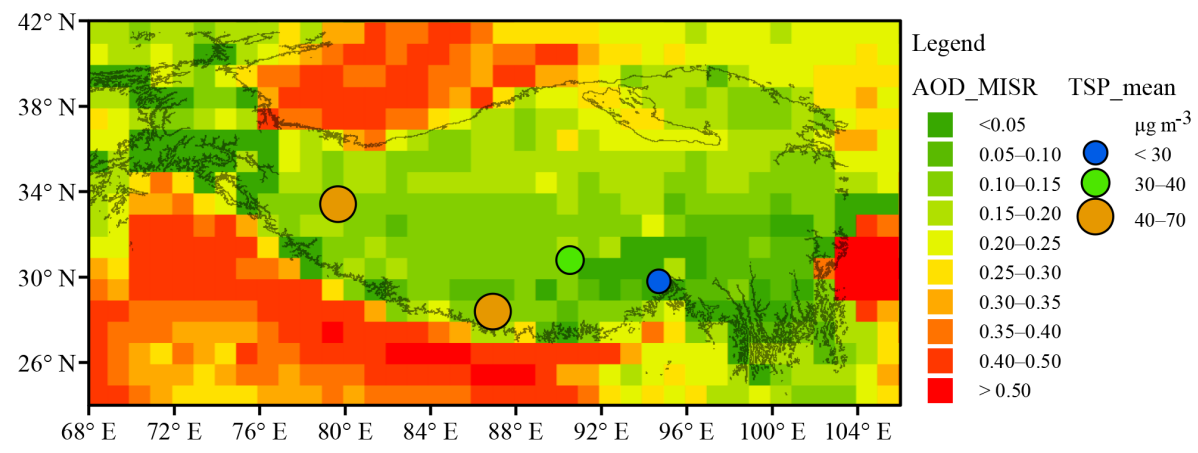

(b) $\mathrm{PM}_{2.5}$ ratio (to TSP) and fine-mode fraction $($ at $550 \mathrm{~nm})$

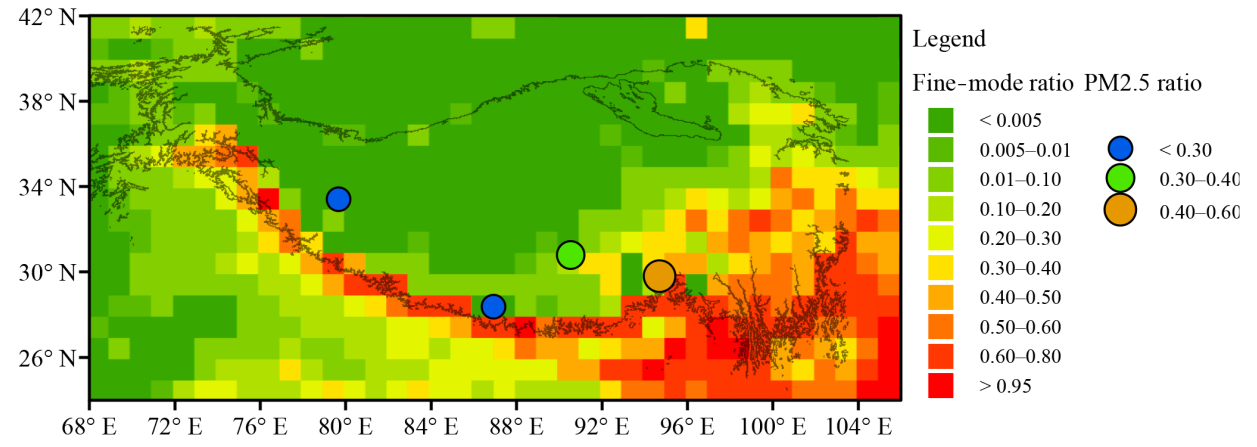

Figure 11. Spatial patterns in AOD and TSP mass (a) and aerosol fine-mode fraction and the ratio of PM 2.5 to TSP (b) over the HTP. (a) Mean MISR AOD (at 550 nm) for 2011-2013 as derived from monthly Level 3 datasets. (b) A time-average map of the MODIS finemode fraction (at $550 \mathrm{~nm}$ ) for 2011-2013, according to monthly Terra (version 5.1) Level 3 values. Ground-based observations are average values sampled in 2011-2013.

between 10:00 and 16:00 LT. This also accounted for the $<1$ daytime-to-nighttime ratio.

\subsection{Spatial and seasonal patterns in atmospheric aerosol masses}

The monthly mean MISR-AOD values for 2011-2013 suggested that HTP atmospheric aerosol masses were generally isolated from surrounding emissions (Fig. 11a). The integrated results of surface-atmospheric aerosol parameters and atmospheric-column aerosol optical properties yielded spatial distributions that suggested that TSP concentrations and MISR-AOD values decreased as land cover varied from barren land, through grassland, to forest (Fig. 11a).

The mean fraction of $\mathrm{PM}_{2.5}$ to TSP was $27.4 \pm 6.65$, $22.3 \pm 10.9,37.3 \pm 11.1$ and $54.4 \pm 6.72 \%$ for the Ngari station, QOMS station, Nam Co station, and SET station, respectively (Fig. 11b). These values increased from barren to forest areas, inversely to TSP masses. The spatial distribution of the aerosol fine-mode fraction (at $550 \mathrm{~nm}$ ) in the time-average map (derived from MODIS) was clearly consistent with the ground-based results recorded at various sites (marked by circles with various colors in Fig. 11b).
Figure 12 shows how MISR-AOD values varied along two cross-sections in different months. These results further confirmed a general decline in AOD from northwest to southeast crossing typical plateau landscapes (section A), and from north to south in the eastern TP (section B). Furthermore, such a spatial pattern was more notable for April-August, coinciding with the appearance of the reported Asian tropospheric aerosol layer during this period (Vernier et al., 2011). This may imply the significance of the development of the Asian tropospheric aerosol layer in modulating the AOD level over this plateau.

TSP mass and MISR-AOD values over HTP forest (SET station) and grassland (Nam Co station) sites shared a common seasonal pattern, with relatively higher values in spring and summer, followed by relatively lower values in autumn and winter (Fig. 13a). At the barren site (QOMS station) there were inconsistent seasonal patterns between surface-atmospheric TSP $\left(\mathrm{PM}_{2.5}\right)$ and atmospheric column AOD (fine-mode AOD) (Fig. 13a, b). Furthermore, there was no correlation between hourly surface $\mathrm{PM}_{2.5}$ mass and fine-mode AOD (at $500 \mathrm{~nm}$ ) at this site (Fig. S4 in the Supplement). Using the Cloud-Aerosol Lidar and Infrared Pathfinder Satellite Observations (CALIPSO), Huang et al. (2007) detected frequent dust plumes in the lower at- 

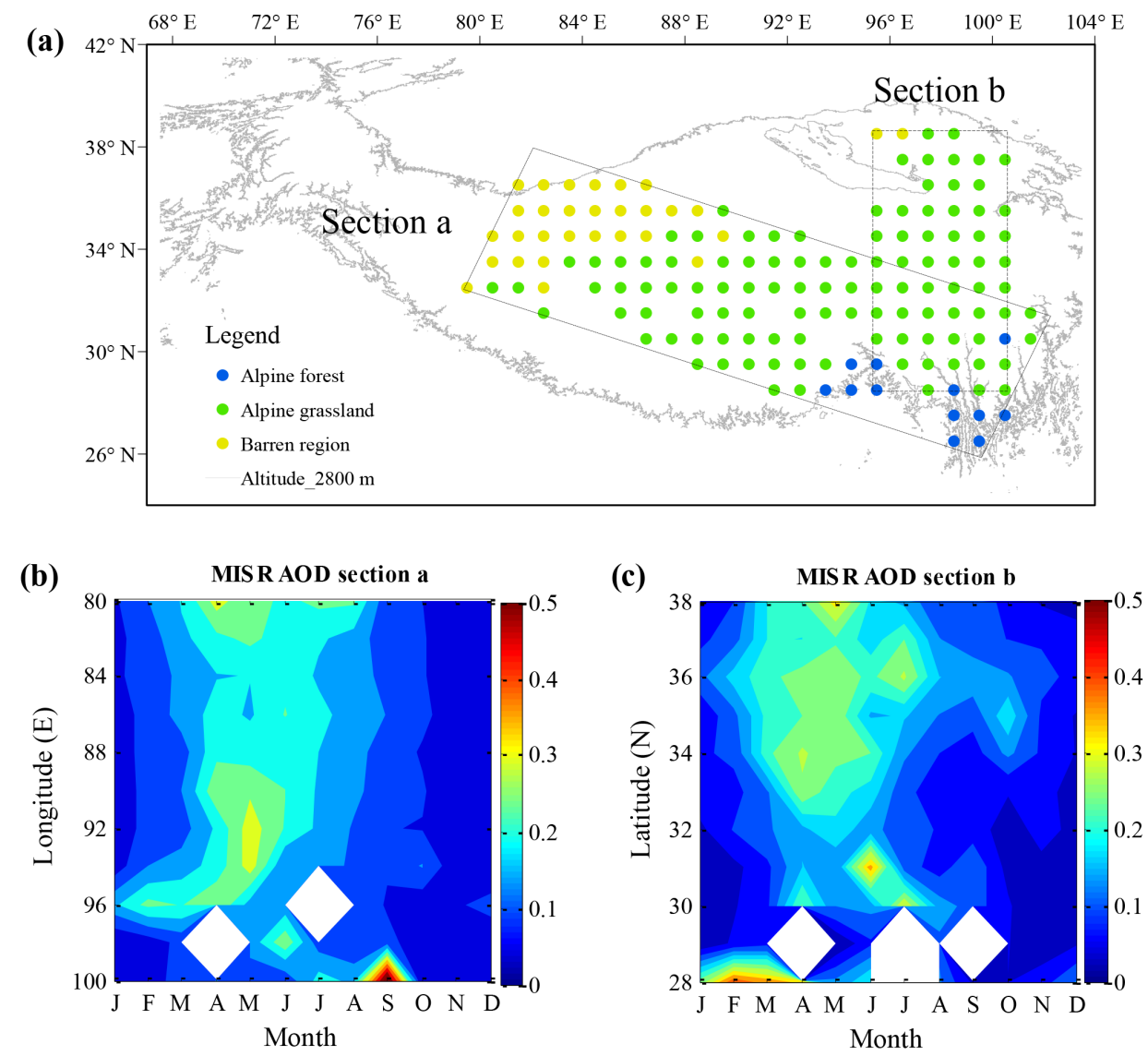

Figure 12. Mean MISR AOD (at $550 \mathrm{~nm}$ ) for two cross-sections during various months in the 2011-2013 period. Missing datasets are plotted in white. The longitudinal section a is from the southeast $\left(100^{\circ} \mathrm{E}, 25.5^{\circ} \mathrm{N}-102^{\circ} \mathrm{E}, 31.5^{\circ} \mathrm{N}\right)$ to the northwest $\left(79.5^{\circ} \mathrm{E}, 32.5^{\circ} \mathrm{N}-81.5^{\circ} \mathrm{E}\right.$, $\left.38.5^{\circ} \mathrm{N}\right)$; the latitudinal section $\mathrm{b}$ is from the south $\left(95^{\circ} \mathrm{E}, 28^{\circ} \mathrm{N}-101^{\circ} \mathrm{E}, 28^{\circ} \mathrm{N}\right)$ to the north $\left(95^{\circ} \mathrm{E}, 39^{\circ} \mathrm{N}-101^{\circ} \mathrm{E}, 39^{\circ} \mathrm{N}\right)$. $\mathrm{J}-\mathrm{D}$ stands for the months of January-December.

mosphere ( $\sim 4-7 \mathrm{~km}$ a.s.l.) of the western HTP. These dust plumes possibly impacted the vertical distribution of aerosol masses over these barren areas.

$\mathrm{PM}_{2.5}$ concentrations and fine-mode AOD values were higher in spring and summer than in autumn and winter at HTP forest and grassland sites but not at the barren site (Fig. 13b). Ratios of $\mathrm{PM}_{2.1}$ to TSP were apparently higher at the SET and Nam Co stations compared to the QOMS station, with a more marked difference in summer and autumn (Fig. 13c). In a background continental atmosphere, fine aerosols mainly originate from biogenic or wildfire emissions. Wildfires were extremely rare in the HTP region, and fire-related emissions from the Asian Brown Cloud occurred only during the winter and spring, as measured in the Himalayan region (Cong et al., 2015; Decesari et al., 2010). Therefore, biogenic emissions and related products may be essential sources of fine aerosols over HTP forest and grassland areas. In the southeastern TP, strong monoterpene emissions were reported since there are a great number of alpine forest species (Wang et al., 2007); biogenic emissions were identified as the main precursors of atmospheric low-weight organic acids (Liu et al., 2014). In the central TP, biogenic contributions to secondary organic carbon were estimated to be $\sim 75 \%$; biogenic aerosol tracer concentrations were also higher in summer than in winter (Shen et al., 2015).

\section{Summary and conclusions}

We studied aerosol mass loadings for the period 20112013 over the highland region of the HTP on both local and regional scales by integrating multistation measurements with satellite and ground-based remote sensing. We found that mass concentrations of these surface atmospheric aerosols were relatively low and varied with land cover, with the general tendency of Ngari and QOMS (barren sites) $>$ Nam Co (grassland site) $>$ SET (forest site). $\mathrm{PM}_{2.5}$ concentrations at these sites were $18.2 \pm 8.9,14.5 \pm 7.4$, $11.9 \pm 4.9$ and $11.7 \pm 4.7 \mu \mathrm{g} \mathrm{m}^{-3}$, respectively. Correspondingly, their fractions to TSP were $27.4 \pm 6.65,22.3 \pm 10.9$, $37.3 \pm 11.1$ and $54.4 \pm 6.72 \%$. Bimodal mass distributions of size-segregated particles were found at all sites, with a rel- 

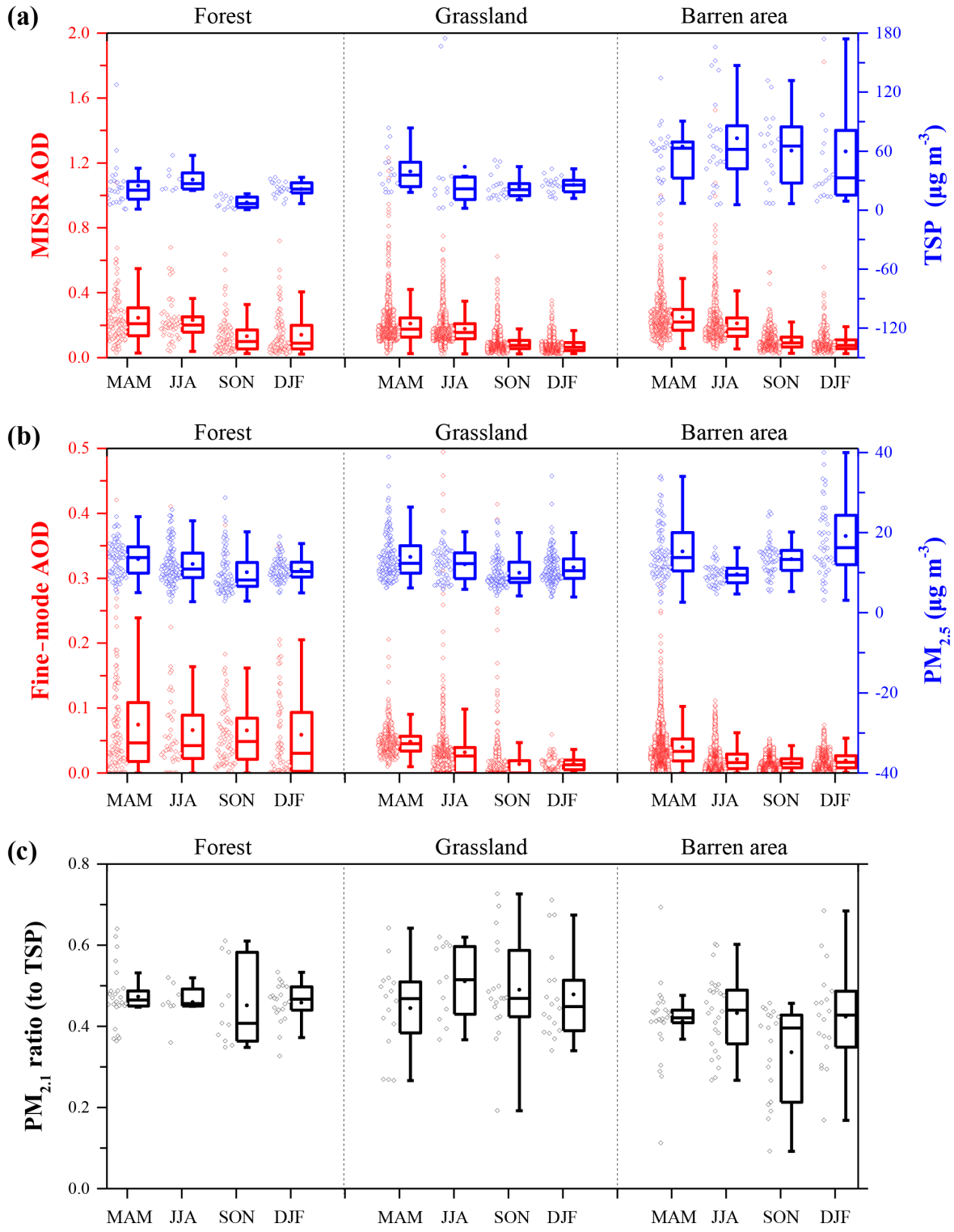

Figure 13. Seasonal characteristics of landscape-classified aerosol masses in the HTP based on in situ observations and remote sensing datasets. Boxes show the percentile values $(25,50,75)$ and whisker plots show maximum and minimum of non-outlier numbers, and the small point within each box is the mean value. The abbreviations are March-May: MAM; June-August: JJA; September-November: SON and December-February: DJF. Please also see the expanded information about Fig. 13 in the Supplement.

atively small peak in accumulation mode and a more marked peak in coarse mode. Diurnal variations in fine aerosol masses generally displayed a bi-peak pattern at the QOMS, Nam Co and SET stations and a single-peak pattern at the Ngari station, controlled by the effects of local geomorphology, mountain-valley breeze circulations and aerosol emissions. Mineral matter content in $\mathrm{PM}_{2.1}$ samples was $26 \%$ at the Ngari station and $29 \%$ at QOMS, or $\sim 2-3$ times that of reported results at human-influenced sites. Furthermore, our observations confirmed that land surface and boundary layer settings create a dynamic for these fine particles to be lifted from the barren land surface into the atmosphere.

Combining surface aerosol and atmospheric-column aerosol optical property data, we found that TSP masses and MISR-AOD values generally decreased as land cover varied from barren to forest, inversely to $\mathrm{PM}_{2.5}$ ratios. The seasonality of aerosol mass parameters was land-cover dependent. Over forest and grassland areas, TSP mass, $\mathrm{PM}_{2.5}$ mass, MISR-AOD and fine-mode AOD values were higher in spring and summer and relatively lower in autumn and winter. Such spatial and seasonal patterns were possibly asso- 
ciated with regional biogenic emissions and related aerosol products. At QOMS, there were inconsistent seasonal patterns between surface TSP mass $\left(\mathrm{PM}_{2.5}\right.$ mass) and atmospheric column AOD (fine-mode AOD).

This study provides new insights on understanding the mass properties of HTP atmospheric aerosols. HTP aerosol masses (especially their regional characteristics and fineparticle emissions) need to be treated sensitively in relation to assessments of their climatic effect and potential role as cloud condensation nuclei and ice nuclei.

\section{Data availability}

All the data presented in this paper are available upon request. Please contact the corresponding authors (Shichang Kang, shichang.kang@lzb.ac.cn or Zhiyuan Cong, zhiyuancong@itpcas.ac.cn).

\section{The Supplement related to this article is available online at doi:10.5194/acp-17-449-2017-supplement.}

Acknowledgements. This research was supported by the Strategic Priority Research Program-Climate Change: Carbon Budget and Relevant Issues (grant no. XDA05100105) and the National Natural Science Foundation of China (grant nos. 41225002, 41271073 and 41501082). The authors gratefully acknowledge the staff at the Ngari, QOMS, Nam Co and SET stations for collecting the aerosol and meteorological datasets and the filter samples used in this study. We also thank the NASA MISR, MODIS teams and AERONET for the MISR, MODIS and AERONET datasets.

Edited by: X. Xu

Reviewed by: two anonymous referees

\section{References}

Babu, S. S., Chaubey, J. P., Krishna Moorthy, K., Gogoi, M. M., Kompalli, S. K., Sreekanth, V., Bagare, S. P., Bhatt, B. C., Gaur, V. K., Prabhu, T. P., and Singh, N. S.: High altitude $(\sim 4520 \mathrm{~m}$ amsl $)$ measurements of black carbon aerosols over western trans-Himalayas: Seasonal heterogeneity and source apportionment, J. Geophys. Res., 116, D24201, doi:10.1029/2011jd016722, 2011.

Broxton, P. D., Zeng, X., Sulla-Menashe, D., and Troch, P. A.: A Global Land Cover Climatology Using MODIS Data, J. Appl. Meteorol. Clim., 53, 1593-1605, 2014.

Cao, J. J., Xu, B. Q., He, J. Q., Liu, X. Q., Han, Y. M., Wang, G. H., and Zhu, C. S.: Concentrations, seasonal variations, and transport of carbonaceous aerosols at a remote Mountainous region in western China, Atmos. Environ., 43, 4444-4452, 2009.

Cong, Z., Kang, S., Kawamura, K., Liu, B., Wan, X., Wang, Z., Gao, S., and Fu, P.: Carbonaceous aerosols on the south edge of the Tibetan Plateau: concentrations, seasonality and sources, Atmos. Chem. Phys., 15, 1573-1584, doi:10.5194/acp-15-15732015, 2015.

Cong, Z. Y., Kang, S. C., Liu, X. D., and Wang, G. F.: Elemental composition of aerosol in the Nam Co region, Tibetan Plateau, during summer monsoon season, Atmos. Environ., 41, 11801187, 2007.

Decesari, S., Facchini, M. C., Carbone, C., Giulianelli, L., Rinaldi, M., Finessi, E., Fuzzi, S., Marinoni, A., Cristofanelli, P., Duchi, R., Bonasoni, P., Vuillermoz, E., Cozic, J., Jaffrezo, J. L., and Laj, P.: Chemical composition of $\mathrm{PM}_{10}$ and $\mathrm{PM}_{1}$ at the high-altitude Himalayan station Nepal Climate ObservatoryPyramid (NCO-P) (5079 ma.s.1.), Atmos. Chem. Phys., 10, 4583-4596, doi:10.5194/acp-10-4583-2010, 2010.

Huang, J., Minnis, P., Yi, Y., Tang, Q., Wang, X., Hu, Y., Liu, Z., Ayers, K., Trepte, C., and Winker, D.: Summer dust aerosols detected from CALIPSO over the Tibetan Plateau, Geophys. Res. Lett., 34, L18805, doi:10.1029/2007GL029938, 2007.

Kang, S., Chen, P., Li, C., Liu, B., and Cong, Z.: Atmospheric aerosol elements over the inland Tibetan Plateau: concentration, seasonality, and transport, Aerosol Air Qual. Res., 16, 789-800, 2016.

Kaufman, Y. J., Smirnov, A., Holben, B. N., and Dubovik, O.: Baseline maritime aerosol: Methodology to Derive the optical thickness and scattering properties, Geophys. Res. Lett., 28, 32513254, 2001.

Kivekäs, N., Sun, J., Zhan, M., Kerminen, V.-M., Hyvärinen, A., Komppula, M., Viisanen, Y., Hong, N., Zhang, Y., Kulmala, M., Zhang, X.-C., Deli-Geer, and Lihavainen, H.: Long term particle size distribution measurements at Mount Waliguan, a highaltitude site in inland China, Atmos. Chem. Phys., 9, 5461-5474, doi:10.5194/acp-9-5461-2009, 2009.

Lau, K., Kim, M., and Kim, K.: Asian summer monsoon anomalies induced by aerosol direct forcing: the role of the Tibetan Plateau, Clim. Dynam., 26, 855-864, 2006.

Lawrence, M. G.: Atmospheric science: Asia under a high-level brown cloud, Nat. Geosci., 4, 352-353, 2011.

Lin, W., Zhu, T., Song, Y., Zou, H., Tang, M., Tang, X., and Hu, J.: Photolysis of surface $\mathrm{O}_{3}$ and production potential of $\mathrm{OH}$ radicals in the atmosphere over the Tibetan Plateau, J. Geophys. Res., 113, D02309, doi:10.1029/2007jd008831, 2008.

Liu, B., Kang, S., Sun, J., Zhang, Y., Xu, R., Wang, Y., Liu, Y., and Cong, Z: Wet precipitation chemistry at a high-altitude site (3,326 m a.s.1.) in the southeastern Tibetan Plateau, Environ. Sci. Poll. Res., 20, 5013-5027, 2013.

Liu, B., Kang, S., Sun, J., Wan, X., Wang, Y., Gao, S., and Cong, Z.: Low-molecular-weight organic acids in the Tibetan Plateau: Results from one-year of precipitation samples at the SET station, Atmos. Environ., 86, 68-73, 2014.

Liu, Y. W., Xu-Ri, Wang, Y. S., Pan, Y. P., and Piao, S. L.: Wet deposition of atmospheric inorganic nitrogen at five remote sites in the Tibetan Plateau, Atmos. Chem. Phys., 15, 11683-11700, doi:10.5194/acp-15-11683-2015, 2015.

Liu, Z., Liu, D., Huang, J., Vaughan, M., Uno, I., Sugimoto, N., Kittaka, C., Trepte, C., Wang, Z., Hostetler, C., and Winker, D.: Airborne dust distributions over the Tibetan Plateau and surrounding areas derived from the first year of CALIPSO lidar observations, Atmos. Chem. Phys., 8, 5045-5060, doi:10.5194/acp-85045-2008, 2008. 
Lüthi, Z. L., Škerlak, B., Kim, S.-W., Lauer, A., Mues, A., Rupakheti, M., and Kang, S.: Atmospheric brown clouds reach the Tibetan Plateau by crossing the Himalayas, Atmos. Chem. Phys., 15, 6007-6021, doi:10.5194/acp-15-6007-2015, 2015.

Maenhaut, W., Raes, N., Chi, X., Cafmeyer, J., Wang, W., and Salma, I.: Chemical composition and mass closure for fine and coarse aerosols at a kerbside in Budapest, Hungary, in spring 2002, X-Ray Spectrom., 34, 290-296, 2005.

Mbourou, G. N. T., Bertrand, J. J., and Nicholson, S. E.: The Diurnal and Seasonal Cycles of Wind-Borne Dust over Africa North of the Equator, J. Clim. Appl. Meteorol., 36, 868-882, 1997.

Ming, J., Cachier, H., Xiao, C., Qin, D., Kang, S., Hou, S., and $\mathrm{Xu}, \mathrm{J}$.: Black carbon record based on a shallow Himalayan ice core and its climatic implications, Atmos. Chem. Phys., 8, 13431352, doi:10.5194/acp-8-1343-2008, 2008.

Ming, J., Du, Z., Xiao, C., Xu, X., and Zhang, D.: Darkening of the mid-Himalaya glaciers since 2000 and the potential causes, Environ. Res. Lett., 7, 014021, doi:10.1088/1748-9326/7/1/014021, 2012.

Panwar, T. S., Hooda, R. K., Lihavainen, H., Hyvarinen, A. P., Sharma, V. P., and Viisanen, Y.: Atmospheric aerosols at a regional background Himalayan site - Mukteshwar, India, Environ. Monit. Assess., 185, 4753-4764, 2013.

Patashnick, H. and Rupprecht, E. G.: Continuous PM-10s Measurements Using the Tapered Element Oscillating Microbalance, J. Air Waste Manage., 41, 1079-1083, 1991.

Qu, B., Ming, J., Kang, S.-C., Zhang, G.-S., Li, Y.-W., Li, C.-D., Zhao, S.-Y., Ji, Z.-M., and Cao, J.-J.: The decreasing albedo of the Zhadang glacier on western Nyainqentanglha and the role of light-absorbing impurities, Atmos. Chem. Phys., 14, 1111711128, doi:10.5194/acp-14-11117-2014, 2014.

Ramanathan, V., Crutzen, P. J., Lelieveld, J., Mitra, A. P., Althausen, D., Anderson, J., Andreae, M. O., Cantrell, W., Cass, G. R., Chung, C. E., Clarke, A. D., Coakley, J. A., Collins, W. D., Conant, W. C., Dulac, F., Heintzenberg, J., Heymsfield, A. J., Holben, B., Howell, S., Hudson, J., Jayaraman, A., Kiehl, J. T., Krishnamurti, T. N., Lubin, D., McFarquhar, G., Novakov, T., Ogren, J. A., Podgorny, I. A., Prather, K., Priestley, K., Prospero, J. M., Quinn, P. K., Rajeev, K., Rasch, P., Rupert, S., Sadourny, R., Satheesh, S. K., Shaw, G. E., Sheridan, P., and Valero, F. P. J.: Indian Ocean Experiment: An integrated analysis of the climate forcing and effects of the great Indo-Asian haze, J. Geophys. Res., 106, 28371-28398, 2001.

Ramanathan, V., Chung, C., Kim, D., Bettge, T., Buja, L., Kiehl, J. T., Washington, W. M., Fu, Q., Sikka, D. R., and Wild, M.: Atmospheric brown clouds: Impacts on South Asian climate and hydrological cycle, P. Natl. Acad. Sci. USA, 102, 5326-5333, 2005.

Shen, R.-Q., Ding, X., He, Q.-F., Cong, Z.-Y., Yu, Q.-Q., and Wang, X.-M.: Seasonal variation of secondary organic aerosol tracers in Central Tibetan Plateau, Atmos. Chem. Phys., 15, 8781-8793, doi:10.5194/acp-15-8781-2015, 2015.

Sheng, J., Wang, X., Gong, P., Joswiak, D. R., Tian, L., Yao, T., and Jones, K. C.: Monsoon-Driven Transport of Organochlorine Pesticides and Polychlorinated Biphenyls to the Tibetan Plateau: Three Year Atmospheric Monitoring Study, Environ. Sci. Technol., 47, 3199-3208, 2013.
Stout, J. E.: Diurnal patterns of blowing sand, Earth Surf. Proc. Land., 35, 314-318, 2010.

Vernier, J. P., Thomason, L. W., and Kar, J.: CALIPSO detection of an Asian tropopause aerosol layer, Geophys. Res. Lett., 38, L07804, doi:10.1029/2010GL046614, 2011.

Wang, Q., Han, Z., Tijian, W., and Yoshiro, H.: An estimate of biogenic emissions of volatile organic compounds during summertime in China, Environ. Sci. Poll. Res., 14, 69-75, 2007.

Willeke, K. and Whitby, K. T.: Atmospheric Aerosols: Size Distribution Interpretation, J. Air Poll. Control Assoc., 25, 529-534, 1975.

Xia, X., Wang, P., Wang, Y., Li, Z., Xin, J., Liu, J., and Chen, H.: Aerosol optical depth over the Tibetan Plateau and its relation to aerosols over the Taklimakan Desert, Geophys. Res. Lett., 35, L16804, doi:10.1029/2008g1034981, 2008.

Xia, X., Zong, X., Cong, Z., Chen, H., Kang, S., and Wang, P.: Baseline continental aerosol over the central Tibetan plateau and a case study of aerosol transport from South Asia, Atmos. Environ., 45, 7370-7378, 2011.

Xin, J., Wang, Y., Pan, Y., Ji, D., Liu, Z., Wen, T., Wang, Y., Li, X., Sun, Y., Sun, J., Wang, P., Wang, G., Wang, X., Cong, Z., Song, T., Hu, B., Wang, L., Tang, G., Gao, W., Guo, Y., Miao, H., Tian, S., and Wang, L.: The Campaign on Atmospheric Aerosol Research Network of China: CARE-China, B. Am. Meteorol. Soc., 96, 1137-1155, 2015.

Xu, B., Cao, J., Hansen, J., Yao, T., Joswia, D. R., Wang, N., Wu, G., Wang, M., Zhao, H., Yang, W., Liu, X., and He, J.: Black soot and the survival of Tibetan glaciers, P. Natl. Acad. Sci. USA, 106, 22114-22118, 2009.

Xu, J., Wang, Z., Yu, G., Qin, X., Ren, J., and Qin, D.: Characteristics of water soluble ionic species in fine particles from a high altitude site on the northern boundary of Tibetan Plateau: Mixture of mineral dust and anthropogenic aerosol, Atmos. Res., 143, 43-56, 2014.

Yan, N., Wu, G., Zhang, X., Zhang, C., Xu, T., and Lazhu: Variation of aerosol optical properties from AERONET observation at Mt. Muztagh Ata, Eastern Pamirs, Atmos. Res., 153, 480-488, 2015.

Zhang, X. Y., Arimoto, R., Cao, J. J., An, Z. S., and Wang, D. Atmospheric dust aerosol over the Tibetan Plateau, J. Geophys. Res.-Atmos., 106, 18471-18476, 2001.

Zhang, Y., Sillanpää, M., Li, C., Guo, J., Qu, B., and Kang, S.: River water quality across the Himalayan regions: elemental concentrations in headwaters of Yarlung Tsangbo, Indus and Ganges River, Environ. Earth Sci., 73, 4151-4163, 2015.

Zhao, Z., Cao, J., Shen, Z., Xu, B., Zhu, C., Chen, L. W. A., Su, X., Liu, S., Han, Y., Wang, G., and Ho, K.: Aerosol particles at a high-altitude site on the Southeast Tibetan Plateau, China: Implications for pollution transport from South Asia, J. Geophys. Res., 118, 11360-11375, 2013. 